\title{
Seasonal activity of ticks infesting domestic dogs in Bejaia province, Northern Algeria
}

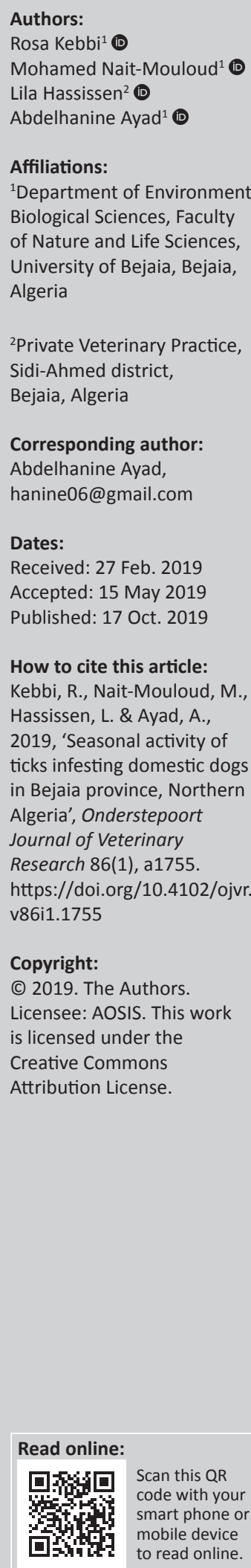

This epidemiological study aimed to determine the species of tick infestation in dogs, their prevalence and dynamic in the Bejaia province, northeastern Algeria. A total of 631 dogs were examined from different localities of the Bejaia province between March 2016 and February 2017. Of the 631 examined dogs, $15 \%$ were infested with one or more tick species. A total of 339 adult ticks were collected and identified, including 199 male tick species and 140 female tick species. Our results revealed that most of these were Rhipicephalus species, with Rhipicephalus sanguineus (51.32\%) being the most prevalent followed by Rhipicephalus bursa (35.1\%) and Rhipicephalus turanicus (12.98\%). Ixodes ricinus represented only $0.6 \%$ of all ticks collected. The highest infested seasons were spring $(22.55 \%)$ and summer $(22.54 \%)$ and the lowest infested seasons were autumn $(8.62 \%)$ and winter $(0.9 \%)$. There is no significant difference between the sex of the animal and the prevalence of infestation $(p=0.837)$. Also, the prevalence of infestation by ticks in young animals was higher than that in adult animals $(p=0.550)$. A significant difference between the prevalence of infestation and animal breed was observed $(p=0.042)$. This study is the first epidemiological investigation conducted on the prevalence of hard ticks infesting domestic dogs in Bejaia (northeastern Algeria) based on conventional methods. It is therefore necessary to implement an effective tick control strategy during infestation periods in order to prevent vector-borne diseases.

Keywords: prevalence; dynamic; ticks; dogs; Bejaia province.

\section{Introduction}

After mosquitoes, ticks are the second most important obligate haematophagous arthropods that parasitise all classes of vertebrates for their blood meal in almost all regions of the world, particularly in Africa (Laamri et al. 2012; Xhaxhiu et al. 2009). They can also crucially transmit to animals, especially dogs, a large number of protozoa and bacteria, such as Babesia, Theileria and Anaplasma spp. (Gray et al. 2013; Marquez-Jimenez et al. 2005). The seasonal dynamics of ticks is likely to affect the transmission of pathogens. Several ecological factors can influence the survival and development of ticks, especially temperature, relative humidity and vegetation cover (Sahibi \& Rhalem 2007). All tick species are significant disease vectors and the increased incidence of these diseases is mainly attributed to climate change that affects ticks directly or indirectly (Gray et al. 2009). Ticks are highly climate-sensitive arthropods, and all stages of their life cycle depend on a complex combination of climatic variables. The presence of hosts and vegetation greatly modulate the dynamics of their populations. However, vegetation is a major modifier of local climatic conditions, to which ticks must adapt for their development and survival (EstradaPeña, Ayllón \& De La Fuente 2012).

Dogs are the most commonly owned companion pets worldwide (Moriello 2003). They are the most successful canids, adapted to human habituation, which contribute to the physical, social and emotional well-being of their owners (Dohoo et al. 1998). It is possible that dogs carry ticks in the domestic environment and transmit these to humans, which may constitute a major concern for public health (Dantas-Torres, Chomel \& Otranto 2012).

In Algeria, very few studies have been conducted on the vectorial role of ticks that infest dogs, except the inventory carried out by Matallah et al. (2013). In terms of biodiversity and specific biology, Ixodidea fauna is not sufficiently known in Algeria (Meddour \& Meddour 2006). Because of certain geographical specifications and the probable presence of different types of ticks infesting companion animals, epidemiology studies of ticks in dogs are extremely important to plan the approaches of pest management. This study aimed at determining the species of tick infestation in dogs, their prevalence and dynamics by performing an epidemiological study in the Bejaia province (northeastern Algeria). 


\section{Material and methods Study area and dogs}

The study was carried out in the Bejaia province of Algeria $\left(36^{\circ} 43^{\prime} \mathrm{N}, 5^{\circ} 04^{\prime} \mathrm{E}\right)$ (Figure 1) from March 2016 to February 2017. The province has four distinct seasons: winter (January to March), spring (April to June), summer (July to September) and autumn (October to December). The annual rainfall in the region during the study period ranged from $679 \mathrm{~mm}$ to $821 \mathrm{~mm}$. The mean maximum summer temperature was $29.9^{\circ} \mathrm{C}$ (August) and the mean minimum winter temperature was $6.4^{\circ} \mathrm{C}$ (January) during the study period (Table 1 ).

A total of 631 dogs were selected randomly from different habitats (home and farmhouse) and localities of the Bejaia province. All dogs were presented to a veterinary clinic for different reasons (care, vaccinations, etc.). A dermatological examination was performed by veterinary practitioners and all observations were recorded for each dog examined throughout the study. A complete examination of the skin, visually and by palpation, was done for the presence of ticks. The age of the animals ranged between a few days and over 15 years, with mixed breeds.

\section{Tick collection and identification}

All ticks were removed carefully to ensure that the mouthparts remained intact. The ticks collected were preserved in

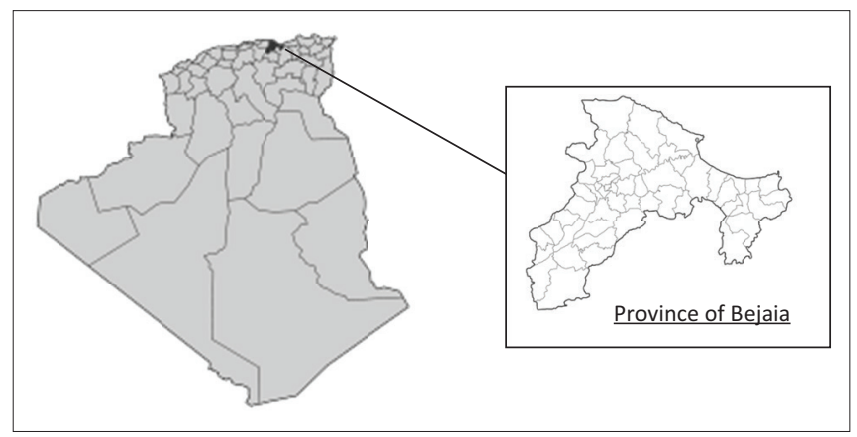

Source: Wikipedia, The free encyclopedia, Municipalities of the province of Bejaia, viewed 25 March 2017, from https://fr.wikipedia.org/wiki/Communes_de_la_wilaya_de_B $\%$ C3 $\%$ A9ja\%C3\%AFa.

FIGURE 1: Map of the study area, Bejaia (Northern Algeria, latitude $36^{\circ} 43^{\prime} \mathrm{N}$ and longitude $\left.5^{\circ} 04^{\prime} \mathrm{E}\right)$. individually labelled plastic containers containing 70\% ethanol. Tick identification was carried out using standard methods at the Laboratory of Animal Biology, University of Bejaia. Each tick was identified using a stereomicroscope (MOTIC, ST-37C-2LOO) according to the standard morphological identification keys (Meddour \& Meddour 2006; Walker et al. 2014)

\section{Statistics analysis}

Prevalence was calculated as the ratio between the number of infested dogs and the total number of examined dogs. Abundance was determined as the ratio between the total number of parasitic species and the total number of examined dogs. Infestation intensity was calculated as the ratio between the total number of parasitic species in hosts and the number of infested hosts. Statistical analyses were carried out using the $\mathrm{R}$ software version 3.4.4 (http://www.R-project.org/). Tick infestation was analysed using the following factors of variation: sex (male and female), age (young: $\leq 12$ months; adult: > 1 year), breed (German Shepherd, Rottweiler, American Staffordshire Terrier, Belgian Shepherd, Dogo Argentino, French Pointer and others) and season (spring, summer, autumn and winter). Statistical analysis was performed using a negative binomial General Linear Model (function 'glm.nb' in library 'MASS' in R). Tukey's post-hoc test was performed using the 'glht' function from the multcomp package. The values were statistically different when the $p$-value was $<0.05$.

\section{Ethical considerations}

Ethical clearance to conduct the study was obtained from the scientific committee of the Faculty of Nature and Life Sciences, University of Bejaia.

\section{Results}

Of the 631 examined dogs, 15\% were infested with one or more tick species. A total of 339 mature ticks were collected and identified, including 199 male and 140 female tick species. The overall prevalence of infestation was found to be 15\% (94/631) during clinical examination.

TABLE 1: Mean \pm standard deviation, minimum and maximum value of temperature, rainfall and humidity per month in the Bejaia area, Algeria (2016-2017).

\begin{tabular}{|c|c|c|c|c|c|}
\hline \multirow[t]{2}{*}{ Months } & \multicolumn{2}{|c|}{ Temperature $\left({ }^{\circ} \mathrm{C}\right)$} & \multicolumn{2}{|c|}{ Rainfall (mm) } & \multirow[t]{2}{*}{ Humidity (\%) } \\
\hline & Mean \pm s.d. & Min-Max & Mean \pm s.d. & Min-Max & \\
\hline March 2016 & $13.1 \pm 3.5$ & $8.3-18.3$ & $199.39 \pm 14.58$ & $0.25-59.94$ & 76.0 \\
\hline April 2016 & $16.1 \pm 1.84$ & $18-21.15$ & $49.27 \pm 3.45$ & $0.25-16$ & 80.0 \\
\hline May 2016 & $18 \pm 2.65$ & $13.6-23.3$ & $55.62 \pm 6.08$ & $0.25-29.97$ & 76.9 \\
\hline June 2016 & $22.3 \pm 1.8$ & $17.3-26.5$ & $19.06 \pm 2.07$ & $1.02-9.91$ & 78.4 \\
\hline July 2016 & $25.3 \pm 1.55$ & $20.2-29.5$ & - & - & 72.9 \\
\hline August 2016 & $25.2 \pm 1.53$ & $20.4-29.9$ & - & - & 73.3 \\
\hline September 2016 & $23.7 \pm 1.8$ & $19-28.8$ & $39.12 \pm 4.61$ & $3.05-20.07$ & 74.7 \\
\hline October 2016 & $22.3 \pm 2.58$ & $18.1-28.3$ & $21.59 \pm 1.8$ & $0.25-5.08$ & 73.0 \\
\hline November 2016 & $17 \pm 3.13$ & $12.7-22.4$ & $43.19 \pm 1.43$ & $1.02-22.1$ & 69.7 \\
\hline December 2016 & $13.6 \pm 1.45$ & $10.1-18.9$ & $41.14 \pm 2.5$ & $0.25-9.91$ & 78.8 \\
\hline January 2017 & $9.9 \pm 2.22$ & $6.4-14.7$ & $266.72 \pm 16.05$ & $0.5-75.95$ & 74.9 \\
\hline February 2017 & $13.3 \pm 2.25$ & $9.2-18.2$ & $51.81 \pm 5.18$ & $0.51-25.91$ & 74.8 \\
\hline
\end{tabular}

Source: Climat Bejaia, Average and total annual climate values, viewed 25 March 2017, from https://fr.tutiempo.net/climat/2016/ws-604020.html.

s.d., standard deviation. 
TABLE 2: Number (male and female) and prevalence of various tick species in dogs in the Bejaia province, northeastern Algeria, between March 2016 and February 2017

\begin{tabular}{lcccc}
\hline Tick species & \multicolumn{3}{c}{ Number of ticks } & Prevalence (\%) \\
\cline { 2 - 4 } & Male & Female & Total & \\
\hline Rhipicephalus sanguineus & 93 & 81 & 174 & 51.32 \\
Rhipicephalus bursa & 74 & 45 & 119 & 35.10 \\
Rhipicephalus turanicus & 32 & 12 & 44 & 12.98 \\
Ixodes ricinus & 0 & 2 & 2 & 0.60 \\
\hline
\end{tabular}

TABLE 3: Prevalence of infested dogs in the Bejaia province, northeastern Algeria, with mixed tick infestations.

\begin{tabular}{lcc}
\hline Tick species & $\begin{array}{c}\text { Prevalence } \\
(\mathbf{\%})\end{array}$ & $\begin{array}{c}\text { Number of } \\
\text { infested dogs }\end{array}$ \\
\hline $\begin{array}{l}\text { Rhipicephalus sanguineus + Rhipicephalus bursa } \\
\text { +Rhipicephalus turanicus }\end{array}$ & 12.76 & 12 \\
$\begin{array}{l}\text { Rhipicephalus sanguineus + Rhipicephalus bursa } \\
\begin{array}{l}\text { Rhipicephalus sanguineus + Rhipicephalus } \\
\text { turanicus }\end{array}\end{array}$ & 13.83 & 13 \\
$\begin{array}{l}\text { Rhipicephalus bursa +Rhipicephalus turanicus } \\
\text { Rhipicephalus sanguineus }\end{array}$ & 5.32 & 5 \\
Rhipicephalus bursa & 3.20 & 3 \\
Rhipicephalus turanicus & 30.85 & 29 \\
Ixodes ricinus & 26.6 & 25 \\
\hline & 6.38 & 6 \\
\hline
\end{tabular}

TABLE 4: Seasonal variation of tick infestation of dogs in the Bejaia province, northeastern Algeria.

\begin{tabular}{lccccc}
\hline Season & Spring & Summer & Autumn & Winter & $\boldsymbol{p}$ \\
\hline Number of examined dogs & 202 & 142 & 177 & 110 & - \\
Number of infested dogs & 46 & 32 & 15 & 1 & - \\
Number of collected ticks & 211 & 87 & 39 & 2 & - \\
Infestation prevalence $\dagger$ & $22.77^{\mathrm{a}}$ & $22.53^{\mathrm{a}}$ & $8.47^{\mathrm{b}}$ & $0.90^{\mathrm{b}}$ & $<0.001$ \\
Tick abundance $\dagger$ & $1.04^{\mathrm{a}}$ & $0.61^{\mathrm{a}}$ & $0.22^{\mathrm{b}}$ & $0.01^{\mathrm{c}}$ & $<0.001$ \\
Infestation intensity§ & $4.58^{\mathrm{a}}$ & $2.71^{\mathrm{a}}$ & $2.60^{\mathrm{a}}$ & $2.00^{\mathrm{a}}$ & 0.025 \\
\hline
\end{tabular}

$\dagger$, (Number of infested dogs/total number of examined dogs) $\times 100$

$\$$ Number of collected ticks/number of examined dogs.

$\S$, Number of collected ticks/number of infested dogs.

$a, b, c$, Values with different superscripts in the different seasons differ statistically at the same parameter $(p<0.05)$.

In this study, two tick genera, Rhipicephalus and Ixodes, were identified based on the external morphological characteristics (Table 2). Our results revealed that among the Rhipicephalus species, Rhipicephalus sanguineus was the most prevalent $(51.32 \%)$, followed by $R$. bursa $(35.1 \%)$ and $R$. turanicus $(12.98 \%)$. Ixodes ricinus only represented $0.6 \%$ of all ticks collected. The ears and neck are the preferred attachment sites of ticks, with a prevalence of $55.8 \%$ and $22.2 \%$, respectively. Mixed infestations with more than one tick species were recorded in the majority of dogs (Table 3).

Table 4 illustrates the seasonal variation of tick infestation in dogs in the Bejaia province. The total tick prevalence peaked during spring and summer (22.55\% and $22.54 \%$, respectively) and the lowest prevalence occurred during winter $(0.9 \%)$ $(p<0.001)$. The abundance and high intensity of ticks were observed in spring (1.04 and 4.58, respectively) and summer (0.61 and 2.71, respectively), but the lowest abundance and intensity were observed in winter (2.00 and 0.01 , respectively) $(p<0.05)$. The monthly variation in the prevalence of infested animals because of $R$. sanguineus, $R$. bursa, $R$. turanicus and I. ricinus is shown in Figure 2. The prevalence rates recorded of infested dogs by $R$. sanguineus, $R$. bursa and $R$. turanicus were very high during April and May. As regards to I. ricinus, a prevalence rate was observed only in December.

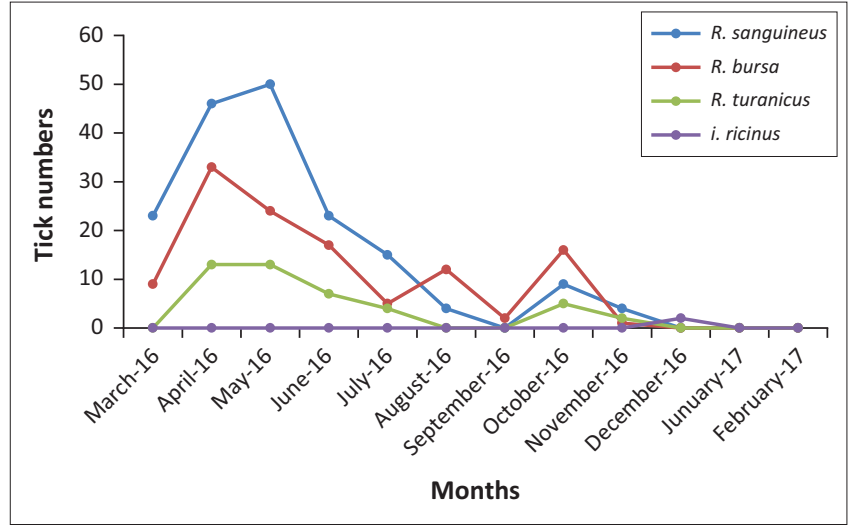

FIGURE 2: Seasonal abundance of ticks (Rhipicephalus sanguineus, Rhipicephalus bursa, Rhipicephalus turanicus and Ixodes ricinus) found on owned dogs in the Bejaia province (2016-2017).

TABLE 5: The variation of the prevalence of tick infestation in dogs with related risk factors (sex, age, breed and season) in the Bejaia province.

\begin{tabular}{|c|c|c|c|c|}
\hline Risk factors & $\begin{array}{c}\text { Number } \\
\text { of examined } \\
\text { dogs }\end{array}$ & $\begin{array}{l}\text { Number of } \\
\text { positive } \\
\text { infested dogs }\end{array}$ & $\begin{array}{c}\text { Tick } \\
\text { prevalence } \\
(\%)\end{array}$ & $p$ \\
\hline \multicolumn{5}{|l|}{ Sex } \\
\hline Male & 266 & 41 & $15.79^{\mathrm{a}}$ & 0.837 \\
\hline Female & 365 & 53 & $14.29^{\mathrm{a}}$ & \\
\hline \multicolumn{5}{|l|}{ Age } \\
\hline Young & 443 & 59 & $14.00^{\mathrm{a}}$ & 0.550 \\
\hline Adult & 188 & 35 & $17.02^{\mathrm{a}}$ & \\
\hline \multicolumn{5}{|l|}{ Breed } \\
\hline German Shepherd & 210 & 36 & $17.14^{\mathrm{a}}$ & 0.042 \\
\hline Rottweiler & 62 & 16 & $25.81^{\mathrm{a}}$ & \\
\hline $\begin{array}{l}\text { American Staffordshire } \\
\text { Terrier }\end{array}$ & 154 & 12 & $8.44^{\mathrm{a}}$ & \\
\hline Belgian Shepherd & 56 & 8 & $14.29^{\mathrm{a}}$ & \\
\hline Dogo Argentino & 24 & 6 & $20.83^{a}$ & \\
\hline French Pointer & 13 & 5 & $38.46^{\mathrm{a}}$ & \\
\hline Otherst & 112 & 11 & $9.82^{\mathrm{a}}$ & \\
\hline \multicolumn{5}{|l|}{ Season } \\
\hline Spring & 202 & 46 & $22.55^{\mathrm{a}}$ & $<0.001$ \\
\hline Summer & 142 & 32 & $22.54^{\mathrm{a}}$ & \\
\hline Autumn & 177 & 15 & $8.62^{b}$ & \\
\hline Winter & 110 & 1 & $0.90^{\mathrm{b}}$ & \\
\hline
\end{tabular}

Note: Age (young: $\leq 1$ year old; adult: $>1$ year old), sex (male and female), breed (German Shepherd, Rottweiler, American Staffordshire Terrier, Belgian Shepherd, Dogo Argentino, French Pointer and others), season (spring, summer, autumn and winter).

$\dagger$, Others: Blue Gascony Basset, Beagle, Poodle, Griffon, Great Dane and Shar-Pei.

$a, b$, Values with different superscripts in the same factor differ statistically $(p<0.05)$.

The variation of prevalence of infestation by sex, age and breed is shown in Table 5. There was no significant difference between the sex of the animal and the prevalence of infestation $(p=0.837)$ and the age of the animal and the prevalence of infestation $(p=0.550)$. Conversely, the prevalence of infestation by ticks in young animals $(\leq 1$ year of age) was higher than that in adult animals ( $>1$ year of age) $(p=0.550)$. Tick prevalence differed significantly between dog breeds $(p=0.042)$.

\section{Discussion}

Ectoparasitic infestation is widespread in wild and domestic animals worldwide, several of which are responsible for diseases (Krčmar et al. 2014; Ranju et al. 2012). In Algeria, several surveys have been conducted to study the population of ticks parasitic in cattle (Aouadi et al. 2017; Boucheikhchoukh 
et al. 2018; Kouidria et al. 2018); however, few structured and published reports are available relating to ticks infesting dogs. The present epidemiological study, extending over 1 year, was conducted to evaluate the spectrum of tick species involved, the levels of infestations and the seasonal dynamic of these ectoparasites.

This study is the first on ticks infesting domestic dogs in the Bejaia province (northeastern Algeria). Our results revealed that the domestic dogs are infested by a variety of tick species, with one or more tick species per infested dog as described previously (Ebrahimzade, Fattahi \& Mohammad 2016; EstradaPeña et al. 2017; Latrofa et al. 2017; Maurelli et al. 2018). The overall prevalence of infestation was slightly low, which could be a result of difficulties in detecting smaller tick life stages (larvae and nymphs) during clinical examination. Studies performed in different countries have shown that the prevalence of infestation by ticks is significantly variable. The prevalence observed in the current study is higher compared to studies from Iran (8.6\%) (Ebrahimzade, Fattahi \& Mohammad 2016) and Albania (3.5\%) (Kumsa \& Mekonnen 2011). However, it is substantially lower than that reported by Matallah et al. (2013) in the Souk-Ahras and El-Kala areas, northeastern Algeria (63\% and $37 \%$, respectively). The low rate observed in this study may be explained by the fact that dogs are better maintained by the use of acaricidal treatments. The prevalence rates suggests that these ticks present a real major health problem for domestic dogs and their owners as supported by several studies (Kumsa \& Mekonnen 2011; Rinaldi et al. 2007).

Based on the identification keys from morphological characteristics that are approved for African countries, the current results describe four tick species, with a predominance $R$. sanguineus. This finding is in agreement with the previous reports (Benredjem et al. 2014; Bessas et al. 2016; Dahmani et al. 2015; Leulmi et al. 2016). A similar finding of the predominance of this tick species in infested dogs has been reported by Matallah et al. (2013) from northeastern Algeria. In 2011, Mosallanejad, Alborzi and Katvandi (2011) observed the same tick species in companion dogs in the Ahvaz District, southwestern Iran. Studies performed in different countries have shown that the number of tick species is highly variable. Bryson et al. (2000) recorded six species of ticks from dogs belonging to people in resource-poor communities in South Africa. Also, De Mato et al. (2008) identified nine species of ixodid ticks from dogs in Mozambique. In Ethiopia, Kumsa and Mekonnen (2011) identified two species of ticks, namely, Amblyomma spp. and Haemaphysalis leachi. The variation reported in previous studies might be attributed to different factors, such as geographical locations, climatic conditions and management practices (Krčmar et al. 2014). Additionally, indirect effects of climate change will impact the number of infected ticks by affecting vegetation (Gray et al. 2009). The correlation between positive cases of vector-borne disease and their geographic distribution, as well as potential risk factors (age, sex, breed, type of dog, habitat and prophylactic treatments), was evaluated previously (Mircean et al. 2012). Also, Lindgren,
Tälleklin and Polfeldt (2000) concluded that the relatively mild climate of the 1990s in Sweden was probably one of the primary reasons for the observed increase in density and geographic range of $I$. ricinus ticks. In addition, similar preferred attachment sites of ticks in dogs were found in previous studies (Foldvari \& Farkas 2005; Krčmar et al. 2014) compared to our data.

Rhipicephalus sanguineus, known as the kennel tick, is the most widespread tick in dogs; however, it can also be found in cattle (Walker et al. 2014). Our results are in agreement with reports by several researchers (De Mato et al. 2008; Horak \& Matthee 2003; Neves \& Horak 2004). Dantas-Torres and Otranto (2017) noted that the life cycle of $R$. sanguineus is adapted to artificial structures such as human habitations and dog kennels. According to Walker et al. (2014), R. bursa is one of the common Rhipicephalus species in northern Africa, and their preferred hosts are sheep, goats, cattle and horses. However, in this study, the presence of $R$. bursa could be explained by the fact that the dogs were in contact with domestic ruminants, for example, farm dogs. On the other hand, the adult $R$. turanicus infests a variety of hosts such as cats, sheep, goats and wild carnivores, while immature stages of the species never infest dogs (Horak et al. 2000).

Our result revealed two cases of I. ricinus ticks collected from companion dogs in the Bejaia area, Algeria. In North Africa, it is known that the ixodid tick species infest livestock, and their adults are present in large numbers only on livestock (Walker et al. 2014). However, I. ricinus has been observed in more than 300 host species, including mammals, birds and reptiles (Gern \& Humair 2002). It is considered as a potential vector of many disease agents (Farkas 2002). This result could be explained by the fact that dogs would have been infested in the wild. According to Walker et al. (2014), all stages of the development of $I$. ricinus climb in vegetation for transfer to the host. Moreover, the most favourable conditions for the development of I. ricinus are in temperatures that are relatively cold and high levels of humidity. Note that the only cases of I. ricinus was found in December.

In this survey, the Rhipicephalus species collected from companion dogs has shown mainly spring activity, while I. ricinus has a winter activity. This could be ascribed to a variety of climatic conditions in this study region. It has been reported that $R$. sanguineus was present in various Maghreb countries of different bioclimatic zones, in which the adult ticks have a seasonal activity from March to November, with a peak activity in May, and it was absent in winter (Bouattour 2002). Moreover, in other studies, the presence of $R$. sanguineus was reported from June to September (Leulmi 2012). In Morocco, Morel (2000) revealed that the seasonal dynamic of $R$. bursa was unimodal, with a peak in activity during the warm season ranging from March to September; this finding is similar to the results of the present study. Likewise, the $R$. turanicus tick species appears in March and disappears in July (Tsatsaris et al. 2016). As shown in Figure 2, R. turanicus has been collected between April and November, with a peak 
infestation in April and May. Concerning the activity period of $I$. ricinus, it agrees with the results reported previously, that is, autumn-winter (Bouattour, Darghouth \& Daoued 1999). In contrast, I. ricinus developed in bimodal mode in the temperate countries, with intense and low activity peaks during spring and autumn, respectively. In the UK, the maximum abundance of I. ricinus has been observed in April and May and their stages show a lesser resurgence in numbers in late summer (Dobson \& Randolph 2011).

In the present study, the overall prevalence of dogs infested by different male tick species was higher than female tick species; however, this was not statistically significant ( $p=0.837)$. Similarly, Ebrahimzade, Fattahi and Mohammad (2016) reported no statistically significant difference in the tick burden between the sexes living in the same ecological environments. In addition, Rodriguez-Vivas et al. (2003) suggested that both sexes are susceptible to ectoparasite infestation. In contrast, Mosallanejad et al. (2011) found a significant difference between male and female tick species infested by ectoparasites ( $35.82 \%$ vs. $20.33 \%$, respectively).

The proportion of infestation caused by the total number of ticks varied between two age groups of dogs. It was the highest in young and the lowest in adult dogs $(p=0.55)$. Studies have shown that the susceptibility of tick infestation is greater in young animals than in adult animals (Moghaddar, Shorigeh \& Gastrodashty 2001; Raut et al. 2006). The influence of age has also been reported by a study in Tunisia, where the frequency of infestation of adult cattle was higher than that of young animals (Bouattour 2001). These results could be because of the immunity system of infected animals which is less developed at an early age (Dillard, Saari \& Anttila 2007).

There is a significant difference between the breed of animal and the prevalence of tick infestation $(p=0.042)$. In contrast, no significant effect to bovine (Benchikh-Elfegoun et al. 2007) and dog (Lorusso et al. 2010) breeds on tick infestation was observed in other studies. On the other hand, a previous study reported that dog breeds have a direct influence on the infestation rate (Silveira, Passos \& Ribeiro 2009). Statistical analysis revealed that German Shepherd breeds are the most infested compared to other breeds examined in this study. Smith et al. (2011) found that dogs with medium hair length were twice as likely to have ticks than dogs with short hair $(p<0.001)$. Dogs characterised by long hair could provide a conducive environment for tick survival compared to shorthaired dogs. It is easy to detect and remove the ticks in the short-haired dogs than those with long hair. Also, shorthaired dogs may be more effective in self-grooming and may remove ticks themselves.

\section{Conclusion}

This study is the first epidemiological investigation conducted on the species of ticks, their prevalence and dynamic in infesting domestic dogs in the Bejaia province (northeastern Algeria) based on conventional methods. Our finding showed the presence of four species infesting dogs, with $R$. sanguineus being the most abundant. The low frequency of ticks in the study area raises concerns about the endemic presence of certain diseases transmitted to dogs. It is therefore necessary to implement an effective tick control strategy during infestation periods in order to prevent vector-borne diseases. Also it is recommended that studies regarding the dynamics of hard ticks in other regions should be conducted to complement the knowledge of Ixodidea fauna in Algeria.

\section{Acknowledgements}

The authors gratefully acknowledge all veterinary colleagues (Dr L. Hassissen, Dr I. Debbouze, Dr N. Djermoune and Dr H. Ghalem) for the help during the sampling and for their hospitality in veterinary practice.

\section{Competing interests}

The authors declare that they have no potential conflict of interest.

\section{Authors' contributions}

R.K. carried out the experimental work and wrote the manuscript. M.N.-M. carried out the statistical analysis. L.H. contributed towards the sampling process. A.A. designed and supervised the experimental study and reviewed the manuscript. All authors have read and approved the final version of the manuscript.

\section{Funding information}

This research received no specific grant from any funding agency in the public, commercial or not-for-profit sectors.

\section{Data availability statement}

Data sharing is not applicable to this article as no new data were created or analysed in this study.

\section{Disclaimer}

The views and opinions expressed in this article are those of the authors and do not necessarily reflect the official policy or position of any affiliated agency of the authors.

\section{References}

Aouadi, A., Leulmi, H., Boucheikhchoukh, M., Benakhla, A., Raoult, D. \& Parola, P., 2017, 'Molecular evidence of tick-borne hemoprotozoan-parasites (Theileria ovis and Babesia ovis) and bacteria in ticks and blood from small ruminants in Northern Algeria', Comparative Immunology, Microbiology \& Infectious Diseases 50, 34-39. https://doi.org/10.1016/j.cimid.2016.11.008

Benchikh-Elfegoun, M.C., Benakhla, A., Bentounsi, B., Bouattour, A. \& Piarroux, R. 2007, 'Identification et cinétique saisonnière des tiques parasites des bovins dans la région de Taher (Jijel) Algérie', Annales de Médecine Vétérinaire 151, 209-214.

Benredjem, W., Leulmi, H., Bitam, I., Raoult, D. \& Parola, P., 2014, 'Borrelia garinii and Rickettsia monacensis in Ixodes ricinus ticks, Algeria', Emerging Infectious Diseases 20(10), 1776-1777. https://doi.org/10.3201/eid2010.140265

Bessas, A., Leulmi, H., Bitam, I., Zaidi, S., Ait-Oudhia, K., Raoult, D. et al., 2016 'Molecular evidence of vector-borne pathogens in dogs and cats and their ectoparasites in Algiers, Algeria', Comparative Immunology, Microbiology \& Infectious Diseases 45, 23-28. https://doi.org/10.1016/j.cimid.2016.01.002 
Bouattour, A., 2001, 'Les tiques de Tunisie: Rôle de Hyalomma detritum dans la transmission de Theileria annulata', PhD thesis Faculty of Sciences, Tunis, p. 247.

Bouattour, A., 2002, 'Clé dichotomique et identification des tiques (Acari: Ixodidae) parasites du bétail au Maghreb', Archives de I'Institut Pasteur de Tunis 79, 43-50.

Bouattour, A., Darghouth, M.A. \& Daoued, A., 1999, 'Distribution and ecology of ticks (Acari, Ixodidae) infesting livestock in Tunisia: An overview of results of 8 years field collection', Parassitologia 41(Suppl 1), 5-10.

Boucheikhchoukh, M., Laroche, M., Aouadi, A., Dib, L., Benakhla, A., Raoult, D. et al., 2018, 'MALDI-TOF MS identification of ticks of domestic and wild animals in Algeria and molecular detection of associated microorganisms', Comparative Immunology, Microbiology \& Infectious Diseases 57, 39-49. https://doi. org/10.1016/j.cimid.2018.05.002

Bryson, N.R., Horak, I.G., Höhnb, W.E. \& Louw, J.P., 2000, 'Ectoparasites of dogs belonging to people in resource-poor communities in North West province, SouthAfrica', Journal of the South African Veterinary Association 71(3), 175-179.

Climat Bejaia, Average and total annual climate values, viewed 25 March 2017, from https://fr.tutiempo.net/climat/2016/ws-604020.html.

Dahmani, M., Loudahi, A., Mediannikov, O., Fenollar, F., Raoult, D. \& Davoust, B., 2015, 'Molecular detection of Anaplasma platys and Ehrlichia canis in dogs from Kabylie, Algeria', Ticks and Tick-Borne Diseases 6(2), 198-203. https://doi. Kabylie, Algeria', Ticks and Tick-Bd
org/10.1016/j.ttbdis.2014.12.007

Dantas-Torres, F., Chomel, B.B. \& Otranto, D., 2012, 'Ticks and tick-borne diseases: A one health perspective', Trends in Parasitology 28(10), 437-446. https://doi. org/10.1016/j.pt.2012.07.003

Dantas-Torres, F. \& Otranto, D., 2017, 'Rhipicephalus sanguineus sl. (Latreille, 1806) (Figs. 127-129)', in A. Estrada-Peña, A. Mihalca \& T. Petney (eds.), Ticks of Europe and North Africa, pp. 323-327, Springer, Cham. https://doi.org/10.1007/978-3319-63760-0 62

De Mato, C., Sitoe, C., Neves, L., Bryson, N.R. \& Horak, I.G., 2008, 'Ixodid ticks on dogs belonging to people in rural communities and villages in Maputo Province, Mozambique', Onderstepoort Journal of Veterinary Research 75(2), 103-108.

Dillard, K.J., Saari, S.A. \& Anttila, M., 2007, 'Strongyloides stercoralis infection in a Finnish kennel', Acta Veterinaria Scandinavica 49(1), 37-42.

Dobson, A.D. \& Randolph, S.E., 2011, 'Modelling the effects of recent changes in climate, host density and acaricide treatments on population dynamics of Ixodes ricinus in the UK', Journal of Applied Ecology 48(4), 1029-1037.

Dohoo, I.R., Mcdonell, W.N., Rhodes, C.S. \& Elazhary, Y.L., 1998, 'Veterinary research and human health', Canadian Veterinary Journal 39(9), 549-556.

Ebrahimzade, E., Fattahi, R. \& Mohammad, B.A., 2016, 'Ectoparasites of stray dogs in Mazandaran, Gilan and Qazvin provinces, North and Center of Iran', Journal of Arthropod-Borne Diseases 10(3), 364-369.

Estrada-Peña, A., Ayllón, N. \& De La Fuente, J., 2012, 'Impact of climate trends on tickborne pathogen transmission, Frontiers in Physiology 3, 64. https://doi. org/10.3389/fphys.2012.00064

Estrada-Peña, A., Roura, X., Sainz, A., Miró, G. \& Solano-Gallego, L., 2017, 'Species of ticks and carried pathogens in owned dogs in Spain: Results of a one-year nationa survey', Ticks and Tick-Borne Diseases 8(4), 443-452. https://doi.org/10.1016/j. ttbdis.2017.02.001

Farkas, R., 2002, 'Tick-borne viral encephalitis of dogs and cats', in F. Beugnet (ed.), Guide to major vector-borne diseases of pets, pp. 179-184, Merial S.A.S, France.

Foldvari, G. \& Farkas, R., 2005, 'Ixodid tick species attaching to dogs in Hungary', Veterinary Parasitology 129(1-2), 125-131. https://doi.org/10.1016/j.vetpar. 2004.11.032

Horak, I.G., Braac, L.E.O., Fourie, L.J. \& Walker, J.B., 2000, 'Parasites of domestic and wild animals in South Africa. XXXVIII. Ixodid ticks collected from 23 wild carnivore specie', Onderstepoort Journal of Veterinary Research 67(4), 239-250.

Horak, I.G. \& Matthee, S., 2003, 'Parasites of domestic and wild animals in South Africa. XLIII. Ixodid ticks of domestic dogs and cats in the Western Cape Province', Onderstepoort Journal of Veterinary Research 70(3), 187-195.

Gern, L. \& Humair, P.F., 2002, 'Ecology of Borrelia burgdorferi sensu lato in Europe', in O. Kahl, J.S. Gray, R.S. Lane \& G. Stanek (eds.), Lyme Borreliosis: Biology, epidemiology and control, pp. 149-174, CABI Publishing, Oxford.

Gray, J., Dantas-Torres, F., Estrada-Pena, A. \& Levin, M., 2013, 'Systematics and ecology of the brown dog tick, Rhipicephalus sanguineus', Ticks and Tick-Borne Diseases 4(3), 171-180. https://doi.org/10.1016/j.ttbdis.2012.12.003

Gray, J.S., Dautel, H., Estrada-Peña, A., Kahl, O. \& Lindgren, E., 2009, 'Effects of climate change on ticks and tick-borne diseases in Europe', Interdisciplinary Perspectives on Infectious Diseases 2009, 593232. https://doi.org/10.1155/2009/593232

Kouidri, M., Ait Amrane, A., Selles, S.M.A., Khellil, C., Smail, F. \& Belhamiti, T.B., 2018 'Survey on species composition of Ixodidae tick infesting cattle in Tiaret (Algeria)', Tropical Agriculture (Trinidad) 95(1), 102-105

Krčmar, S., Ferizbegović, J., Lonić, E. \& Kamberović, J., 2014, 'Hard tick infestation of dogs in the Tuzla area (Bosnia and Herzegovina)', Veterinarski Arhiv 84(2), 177-182.

Kumsa, B.E. \& Mekonnen, S., 2011, 'Ixodid ticks, fleas and lice infesting dogs and cats in Hawassa, southern Ethiopia', Onderstepoort Journal of Veterinary Research 78(1), 326. https://doi.org/10.4102/ojvr.v78i1.326

Laamri, M., El Kharrim, K., Boukbal, M., Belghyti, D. \& Mrifag, R., 2012, 'Dynamique des populations de tiques parasites des bovins de la région du Gharb au Maroc', Revue d'Elevage et de Médecine Vétérinaire des Pays Tropicaux 65(3-4), 57-626. https://doi.org/10.19182/remvt.10123

Latrofa, M.S., Angelou, A., Giannelli, A., Annoscia, G., Ravagnan, S. \& Dantas-Torres, F., 2017. 'Ticks and associated pathogens in dogs from Greece', Parasites \& Vector 10(1), 301. https://doi.org/10.1186/s13071-017-2225-2
Leulmi, H., 2012, 'L’apport de la biologie moléculaire dans la détection des pathogènes vectorisés par les ectoparasites au niveau de la zone humide d'El-Tarf', Master thesis, Veterinary Sciences Institute, El-Tarf, Algeria.

Leulmi, H., Aouadl, A., Bitam, I., Bessas, A., Benakhla, A., Raoult, D. et al., 2016 'Detection of Bartonella tamiae, Coxiella burnetii and rickettsiae in arthropods and tissues from wild and domestic animals in northeastern Algeria', Parasites \& Vectors 9(1), 27. https://doi.org/10.1186/s13071-016-1316-9

Lindgren, E., Tälleklint, L. \& Polfeldt, T., 2000, 'Impact of climatic change on the northern latitude limit and population density of the disease-transmitting European tick Ixodes ricinus', Environmental Health Perspectives 108(2), 119-123. https://doi.org/10.1289/ehp.00108119

Lorusso, V., Dantas-Torres, F., Lia, R.P., Tarallo, V.D., Mencke, N., Capelli, G. et al., 2010, 'Seasonal dynamics of the brown dog tick, Rhipicephalus sanguineus, on a confined dog population in Italy', Medical and Veterinary Entomology 24(3), 309-315. https://doi.org/10.1111/j.1365-2915.2010.00885.x

Marquez-Jimenez, F.J., Hidalgo-Pontiveros, A., Contreras-Chova, F., RodriguezLiebana, J.J. \& Muniain-Ezcurra, M.A., 2005, 'Las garrapatas (Acarina: Ixodoidae) como transmisores y reservorios de microorganismos patógenos en España", Enfermedades Infecciosas y Microbiología Clínica 23(2), 94-102. https://doi. org/10.1157/13071613

Matallah, F., Benakhla, A. \& Bouattour, A., 2013, 'Infestation du chien par Rhipicephalus sanguineus dans deux régions de l'extrême nord-est de l'Algérie', Revue d'élevage et de médecine vétérinaire des pays tropicaux 66(3), 97-101. https://doi.org/ 10.19182/remvt.10137

Maurelli, M., Pepe, P., Colombo, L., Armstrong, R., Battisti, E., Morgoglione, M.E. et al., 2018, 'A national survey of Ixodidae ticks on privately owned dogs in Italy', Parasites \& Vectors 11(1), 420. https://doi.org/10.1186/s13071-018-2994-2

Meddour, B.K. \& Meddour, A., 2006, 'Clés d'identification des Ixodina (Acarina) d'Algérie', Sciences \& Technologie 24, 32-42.

Mircean, V., Dumitrache, M.O., Györke, A., Pantchev, N., Jodies, R., Mihalca, A.D. et al 2012 , 'Seroprevalence and geographic distribution of Dirofilaria immitis and tickborne infections (Anaplasma phagocytophilum, Borrelia burgdorferi sensu lato, and Ehrlichia canis) in dogs from Romania', Vector-Borne and Zoonotic Diseases 12(7), 595-604. https://doi.org/10.1089/vbz.2011.0915

Moghaddar, S., Shorigeh, J. \& Gastrodashty, A.R., 2001, 'Prevalence of ectoparasites and its seasonal prevalence in dogs in Shiraz (Iran)', XII National Congress of Veterinary Parasitology, Abstract 62(S-2), 32.

Morel, P.C., 2000, 'Maladies à tiques du bétail en Afrique', in C. Chartier, J. Itard, P.C. Morel \& P.C. Troncy (eds.), 'Précis de parasitologie vétérinaire et tropicale, Cachan, France', in Lavoisier technique \& documentation, pp. 456-550, Ministere de la Cooperation et du Developpement, Maisons-Alfort.

Moriello, K.A., 2003, 'Zoonotic skin diseases of dogs and cat', Animal Health Research Reviews 4(2), 157-168.

Mosallanejad, B., Alborzi, A.R. \& Katvandi, N., 2011, 'A survey on ectoparasite infestations in companion dogs of Ahvaz district, south-west of Iran', Journal of Arthropod-Borne Diseases 6(1), 70-78.

Neves, A.S. \& Horak, I.G., 2004, 'Ixodid ticks on dogs in and around Maputo and elsewhere in Mozambique', Onderstepoort Journal of Veterinary Research 71(4), 279-283.

Ranju, U.R.S., Latha, B.R.V., Leela, V. \& Basith, S.A., 2012, 'The effect of 1-octen-3-ol, the ruminant kairomone on ixodid tick larvae', Veterinarski Arhiv 82(6),609-615.

Raut, P.A., Mask, D.K., Jayraw, A.K. \& Sonkusale, V.G., 2006, 'Ectoparasitism in dogs from the eastern zone of Maharashtra state', Journal of Parasitic Diseases 30(2), 138-141.

Rinaldi, L., Spera, G., Musella, V., Carbone, S., Veneziano, V., lori, A. et al. 2007 'A survey of fleas on dogs in southern Italy', Veterinary Parasitolgy 148(3-4), 375-378. https://doi.org/10.1016/j.vetpar.2007.06.036

Rodriguez-Vivas, R., Ortega-Pacheco, A., Rosado-Aguilar, J.A. \& Bolio, G.M., 2003, 'Factors affecting the prevalence of mange-mite infestations in stray dogs of Yucatan, Mexico', Veterinary Parasitology 115(1), 61-65.

Sahibi, H. \& Rhalem, A., 2007, 'Tiques et maladies transmises par les tiques chez les bovins au Maroc. Transfert de technologie en agriculture', Bulletin d'information et de liaison PNTTA 151, 1-4.

Silveira, J.A., Passos, L.M. \& Ribeiro, M.F., 2009, 'Population dynamics of Rhipicephalus sanguineus (Latrielle, 1806) in Belo Horizonte, Minas Gerais state, Brazil', Veterinary Parasitology 161(3-4), 270-275. https://doi.org/10.1016/j.vetpar. Veterinary $P$ ara
2009.01.028

Smith, F.D. Ballantyne, R., Morgan, E.R. \& Wall, R., 2011 'Prevalence, distribution and risk associated with tick infestation of dogs in Great Britain' Medical and Veterinary Entomology 25(4), 377-384. https://doi.org/10.1111/j.1365-2915. Veterinary Entor

satsaris, A., Chochlakis, D., Papadopoulos, B., Petsa, A., Georgalis, L., Angelakis, E. et al., 2016, 'Species composition, distribution, ecological preference and host association of ticks in Cyprus', Experimental and Applied Acarology 70(4), host association of ticks in Cyprus', Experimental and
523-542. https://doi.org/10.1007/s10493-016-0091-9

Walker, A.R., Bouattour, A., Camicas, J.L., Estrada-Peña, A., Horak, I.J., Latif, A.A. et al., 2014, Ticks of domestic animals in Africa: A quide to identification of species, 2014, Ticks of domestic animals
Bioscience Reports, Edinburgh.

Wikipedia, The free encyclopedia, Municipalities of the province of Bejaia, viewed 25 March 2017, from https://fr.wikipedia.org/wiki/Communes_de_la_wilaya de $\mathrm{B} \% \mathrm{C} 3 \% \mathrm{~A} 9 \mathrm{ja} \% \mathrm{C} 3 \% \mathrm{AFa}$

Xhaxhiu, D., Kusi, I., Rapti, D., Visser, M., Knaus, M., Lindner, T. et al., 2009, 'Ectoparasites of dogs and cats in Albania', Parasitology Research 105(6), 1577-1587. https://doi.org/10.1007/s00436-009-1591-x 